\title{
Inhibition Effect of Cnidium officinale Makino Extracts on MMP1 Expression in Human Dermal Fibroblasts
}

\author{
Young-Joo Kim \\ Department of Beauty Care and Cosmetics, Osan University, Osan-si, Gyeonggi-do, Korea
}

Corresponding author: Young-Joo Kim, Department of Beauty Care and Cosmetics, Osan University, 45 Chunghak-ro, Osan-si, Gyeonggi-do, 18119, Korea

Tel.: +82313702561

Fax: +82 234365594

Email: blue@osan.ac.kr

Received October 30, 2017

Revised November 14, 2017

Accepted November 22, 2017

Published March 30, 2018

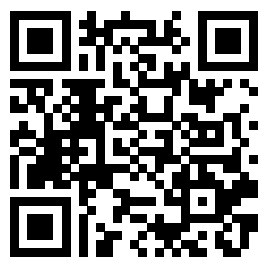

\begin{abstract}
Purpose: Cnidium officinale Makino ( $C$. officinale) belonged to Umbelliferae family is medical herb native to China and is extensively cultivated in Korea, China and Japan. C. officinale has been used to oriental medicine against pain, inflammation, menstrual disturbance, and anti-vitamin deficiency disease, and also acts as a blood pressure depressant. However, effects of $C$. officinale are not fully understood in dermis. Therefore, in this study, we identified effects of $C$. officinale in dermal fibroblast. Methods: Matrix metalloproteinase-1 (MMP1) expression of $C$. officinale extract was valuated using quantitative real time polymerase chain reaction (qRT-PCR). In addition, transcriptional activity of activator protein 1 (AP-1) and c-Jun N-terminal protein kinase (JNK) activity were assayed using luciferase assay and western blot. Results: Extracts of $C$. officinale decreased MMP1 expression in ultraviolet (UV)-exposed human dermal fibroblasts. Moreover, $C$. officinale extracts showed decrease of AP-1 transcriptional activity and phospho-JNK in UV-exposed human dermal fibroblasts. Conclusion: Our results suggest that $C$. officinale extracts decreased MMP1 expression using decreasing AP-1 transcriptional activity and phospho-JNK. Therefore, $C$. officinale extracts has potential to reduce formation of wrinkle and to use as a cosmetic ingredient.
\end{abstract}

Keywords: MMPs, AP-1, JNK, Cnidium officinale Makino, UV

\section{Introduction}

피부의 기능은 내부의 기관을 외부 환경으로부터 보호하 는 것이다(Kalinin et al., 2002). 피부는 표피, 진피, 피하 지방으로 구분되는데 진피는 표피 밑에 있는 층으로 주로 세 포 외 기질(extracellular matrix proteins, ECM)로 구성되 어 있다(Epstein \& Munderloh, 1978). UV는 피부의 구조와 기능을 조절하는 인자 중 하나로 만성적인 UV 노출은 피부 의 광노화를 유발한다(Bae et al., 2010). 이러한 노화피부에 서는 주름, 피부처짐, 색소이상 등의 특성이 나타난다(Lee et al., 2008; Kim et al., 2005). Matrix metalloproteinases $(\mathrm{MMPs})$ 는 구조적으로 기질 분해 효소로써 광노화에 중요 한 역할을 하고, 세포성장과 세포이동, 세포분화, 혈관생성, 세포사멸 등에도 역시 중요하다(Overall \& López-Otin, 2002; Werb, 1997). MMP family중 MMP1은 collagen을 분해하여 피부 내에 collagen과 elastin으로 이뤼진 원섬유
아교질을 분해한다(Chung et al., 2001). 일반적으로 자외선 에 의해서 $\mathrm{MMPS}$ 의 발현과 활성이 조절되는데, 자외선을 조 사받게 되면 mitogen-activated protein kinase (MAPK) 에 의한 신호전달을 거쳐 전사인자인 $\mathrm{AP}-1$ 을 조절하게 된다 (Whitmarsh \& Davis, 1996). AP-1은 c-Jun과 Fos family 의 복합체로 $\mathrm{MMP}$ 의 발현과 collagen 생성저해 기능을 가진 다(Janulis et al., 1999). 자외선을 포함한 대부분의 외부 자 극원들은 $\mathrm{JNK}, \mathrm{ERK}, \mathrm{P} 38$ 과 같은 MAPK를 조절하고 Jun과 Fos의 발현 및 활성을 조절하여 세포외 기질을 분해 또는 합 성한다(Hibi et al., 1993; Yu et al., 2013).

약용식물인 천궁의 학명은 Cnidium officinale Makino 으로 아시아를 중심으로 오랜기간동안 천연의약품으로 사 용되어왔다(Chevallier, 2000). 천궁은 다년생 식물로 산 형과에 속하고, sedative, anti-anaemia, anti-fungal, smooth muscle relaxing, anti-complementary와 같은 다양한 의학적 활성을 가지는 휘발성의 phthalide 유도체들 
을 함유하고 있으며, 천궁 자체 역시도 혈액순환과 염증성질 환에 탁월한 효과가 있는 것으로 알려져 있다(Choi et al., 2002; Jang, 2017; Tahara et al., 1999; Wang et al., 1989). 전통의약에서는 pain, inflammation, menstrual disturbances 등을 치료하는 효능을 가지고 있는 것으로 알 려져 있고, 울혈과 염증억제를 통해 염증성질환에서 혈액순환 에 의한 가려움증을 억제할 수 있다고 알려져 있다(Higashi, 1996). 또한 ddY mice와 hepatic carcinoma cells에서 항암 및 항전이 활성을 가지는 것으로 밝혀졌다(Haranaka et al., 1985; Onishi et al., 1998). 하지만 천궁추출물이 피부에서 의 어떠한 역할을 할 수 있을지에 대해서는 아직 밝혀지지 않 았다. 그러므로 본 연구논문에서는 천궁의 피부세포에서 생리 학적 기능에 대해서 밝히려고 한다.

\section{Methods}

\section{1. 세포배양 및 추출물 제조}

인간진피섬유아세포(normal human dermal fibroblasts, $\mathrm{HDFs}$ )는 Lonza (Basel, Switzerland)에서 구매하였으며, Dulbecco's modified Eagle's medium (DMEM; Gibco, Thermo Fisher Scientific, USA)에 10\% fetal bovine serum (FBS; Sigma-Aldrich, USA)와 10\% penicillin (Gibco, 100 units/mL), 10\% streptomycin (Gibco, $100 \mu$ $\mathrm{g} / \mathrm{mL}$ )이 포함된 배지에 배양하였다. 인간진피섬유아세포는 15 계대 이하의 세포를 사용하여 실험을 진행하였다. 천궁추출 물은 천궁(Nonghyup, Korea)을 잘 세척하여서 건조하고, 건 조된 천궁을 분쇄기(SMX-5800LM; Shinil, Korea)에 분쇄 하여 $100 \mathrm{~g}$ 을 $70 \%$ ethanol $1 \mathrm{~L}$ 에 넣고 $60^{\circ} \mathrm{C}$ 에서 $30 \mathrm{~min}$ 동 안 $20 \mathrm{kHz}$ 이상의 초음파(Ultrasonic cleaner 8891; ColeParmer, USA)를 이용하여 추출하였다. 추출 후 거름종이 (Whatman No.2; GE Healthcare Life Sciences, USA)를 통해 추출하고 남은 천궁 고형파우더를 제거하였고, 걸러진 추출액은 감압농축기((EYELA N-3010; Tokyo Rikakikai, Japan)와 동결건조기(LP 10-30; Ilshin, Korea)로 말 려 분말화하고, 다시 정량 후 dimethyl sulfoxide (DMSO; Biopure, Canada)에 녹여 실험에 사용하였다.

\section{Cell viability 측정}

추출물에 의한 독성을 측정하기 위해서 3-(4,5- Dimethylthiazol -2-yl)-2,5-diphenyltetrazolium bromide (MTT) assay 를 이용하였다. 96 well plate에 인간진피섬유아세포를 $5 \times$ $10^{3}$ cells/well 접종하여 $24 \mathrm{~h}$ 배양하였다. $24 \mathrm{~h}$ 후 추출물을 0-200 $\mu \mathrm{g} / \mathrm{mL}$ 처리하고, $24 \mathrm{~h}$ 배양 후 $0.5 \mathrm{mg} / \mathrm{mL}$ 의 농도가 되도록 MTT stock solution (Sigma-Aldrich)을 넣어주었다. 이후 $37^{\circ} \mathrm{C}$ 에 $1 \mathrm{~h}$ 배양한 후 배지를 제거하고, $100 \mu \mathrm{L} \mathrm{DMSO}$ 를 이용하여 MTT formazan을 녹여주었다. 이후 microplate reader (SpectraMax ${ }^{\circledR}$ i3x; Molecular Devices, USA)에서 $595 \mathrm{~nm}$ 의 파장으로 흡광도를 측정하여 cell viability를 측정 하였다.

\section{MMP1 mRNA 정량}

Total RNA는 Trizol (Invitrogen, USA)을 이용하여 추출 하였다. 추출된 $2 \mu \mathrm{g}$ total RNA는 oligo dT $2 \mu \mathrm{g}$, reverse transcriptase mix (Enzynomics, Korea)를 이용해서 cDNA 를 합성하였고, 합성된 $\mathrm{cDNA}$ 와 $0.2 \mu \mathrm{g} / \mathrm{mL}$ primers (Bionic, Korea; Table 1), 50 mM KCl (Biopure, Canada), 20 mM Tris/HCl pH8.4 (Biopure), 0.8 mM dNTP (Takara, Japan), 0.5 U Extaq DNA polymerase (Takara), 3 mM $\mathrm{MgCl}_{2}$ (Takara), 1X SYBR green (Invitrogen)를 혼합하여 LinegeneK (BioER, China)을 이용 하여 qRT-PCR을 수행 하였다. 측정 후 normalization을 위해 동일 $\beta$-actin 발현량 에 다른 $M M P 1$ 발현량을 계산하였다.

\section{4. $\mathrm{AP}-1$ promoter 전사활성 측정}

Reporter plasmid (pGL-TRE, $1 \mu \mathrm{g}$; Promega, USA)와 normalization plasmid (pCMV- $\beta$-gal, $0.2 \mu \mathrm{g}$; Promega) 을 HilyMax (Dojindo, Japan)를 이용하여 인간진피섬유아 세포에 유전자를 도입하고, $24 \mathrm{~h}$ 동안 안정화를 시킨 후 천 궁추출물을 처리하고, UVA를 조사하였다. 이후 수확하여 $1 \mathrm{X}$ luciferase lysis buffer (Promega, USA)로 세포를 용해하고, $4^{\circ} \mathrm{C}, 12000 \mathrm{rpm}$ 으로 $10 \mathrm{~min}$ 간 원심분리 하여 cell lysate 를 얻었다. $\mathrm{AP}-1$ 의 전사활성은 cell lysate와 luciferase reagent (Promega)를 혼합하여 나오는 발광량을 Veritas ${ }^{\mathrm{TM}}$ Microplate Luminometer (Turner BioSystems, USA)로 측

Table 1. Sequence of primers

\begin{tabular}{ll}
\hline Primers & Sequence \\
MMP1 forward primer & 5'-CTTTCTGGAAGGGCAAGGAC-3' \\
MMP1 reverse primer & 5'-TTGCCTCCCATCATTCTTCA-3' \\
$\beta$-actin forward primer & 5'-CGACAGGATGCAGAAGGAG-3' \\
$\beta$-actin reverse primer & 5'-ACATCTGCTGGAAGGTGGA-3' \\
\hline
\end{tabular}




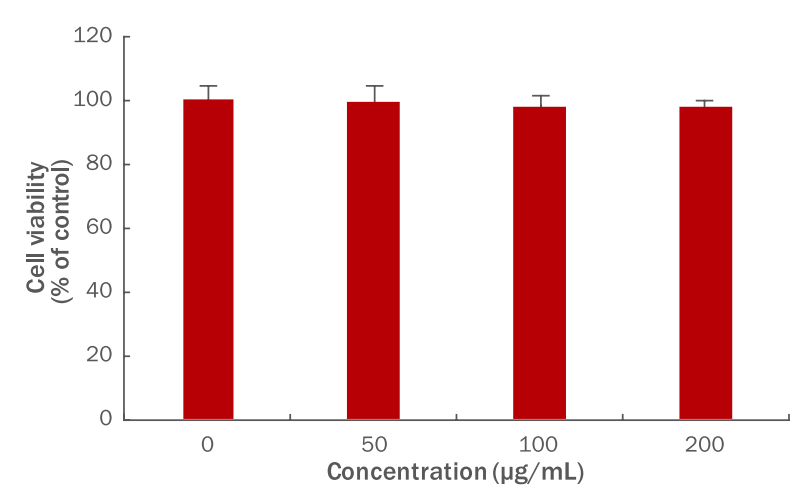

Figure 1. Cytotoxicity of extracts of $\boldsymbol{C}$. officinale in human dermal fibroblasts.

Effects of $C$. officinale extracts on the cell viability in human dermal fibroblasts. Cytotoxicity was exhibited as a percentage of control at the indicated concentrations. Values are expressed as $\mathrm{M} \pm \mathrm{S}$.D. from triplicate experiments. $C$. officinale, Cnidium officinale Makino; $\mathrm{M} \pm S$.D., mean \pm standard deviation.

정하였으며, normalization을 위해서 $\beta$-galatosidase의 활 성을 $\mathrm{O}-$ nitrophenyl- $\beta-\mathrm{D}-$ galactopyranoside (ONPG) assay로 측정하여 luciferase assay값을 보정하였다.

\section{JNK 인산화 측정}

c-Jun N-terminal kinase (JNK)의 활성 척도인 인 산화를 보기 위해서 JNK와 phospho-JNK의 단백질량을 western blot을 이용하여 측정하였다. 천궁추출물을 조건별 로 처리하고 수확된 각각의 샘플에서 RIPA buffer [50 mM Tris-Cl (pH 7.5; Biopure), 150 mM NaCl (Biopure), 1\% NP-40 (Biopure), 0.5\% sodium deoxycholate (Biopure), $0.1 \%$ sodium dodecyl sulfate (SDS; Biopure), protease inhibitor (Biopure)]를 이용하여 세포 내 모든 단백질 을 추출하였다. 추출된 단백질은 sodium dodecyl sulfate polyacrylamide gel electrophoresis (SDS-PAGE)에 전기 영동하여 단백질 크기 별로 분리하고, 이를 nitrocellulose membrane (Whatman)로 옮겨 anti-JNK, anti-p-JNK (Cell Signaling Technology, USA)로 JNK와 phospho$\mathrm{JNK}$ 의 단백질량을 검출하였다.

\section{6. 통계처리}

본 실험의 모든 실험은 3 회 반복하여 진행하였고, 조건 간 의 차이에 대한 유의성을 입증하는 방법으로 Student's $t$-test 을 이용하였다. Student's $t$-test 결과 $p<0.05$ 의 값을 유의성 있다고 판단하고, 유의적인 값에는 별표(*)를 하였다.

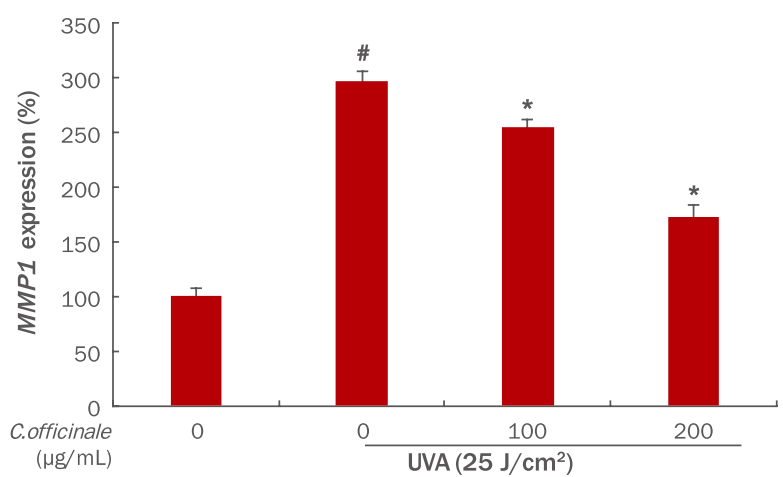

Figure 2. Effects of extracts of $C$. officinale on MMP1 mRNA expression in human dermal fibroblasts.

Effects of MMP1 mRNA expression was measured by qRT-PCR. Expression levels of MMP1 were normalized by $\beta$-actin. The graphs are expressed as $M \pm S$.D. from triplicate experiments. $C$. officinale, Cnidium officinale Makino; MMP1, matrix metalloproteinase-1; qRT-PCR, quantitative real time polymerase chain reaction; ${ }^{*} p<0.05$ compared with control cells; " $p<0.05$ compared with UVA-exposed cells; UVA, ultraviolet $A ; M \pm S . D$., mean \pm standard deviation.

\section{Results and Discussion}

\section{1. 인간진피섬유아세포에서 천궁추출물의 세포독성 확인}

인간진피섬유아세포에 천궁추출물에 의한 세포독성을 확인하 기 위해서, 천궁 추출물을 0-200 $\mu \mathrm{g} / \mathrm{mL}$ 로 인간진피섬유아세포 에 $24 \mathrm{~h}$ 처리 후 세포 생존율을 측정하였다. $200 \mu \mathrm{g} / \mathrm{mL}$ 농도 까지 세포의 성장억제가 일어나지 않는 것을 확인하였고, 이에 따라 천궁추출물의 독성이 없는 농도로 확인된 $200 \mu \mathrm{g} / \mathrm{mL}$ 이 하에서 $M M P 1$ 의 발현 변화를 측정하였다(Figure 1).

\section{2. 인간진피섬유아세포에서 천궁추출물에 의한 MMP1 발현 변} 화

광노화 피부에서는 진피 탄력도가 떨어지는데 이는 진피 섬유아세포에서 $M M P 1$ 을 과도하게 발현하여 노화가 진행되 는 것으로 알려져 있다(Chiang et al., 2012; Cho et al., 2010). 발현된 $M M P 1$ 은 collagen의 분해를 일으켜 진피 탄 력을 떨어뜨리고 이를 통해서 피부 주름이 발생하기 때문에 (Choi et al., 2016; Lee et al., 2017; Tran et al., 2015) 인 간진피섬유아세포에서 자외선에 의해서 증가된 $M M P 1$ 의 발 현이 천궁추출물에 의해서 조절되는지 확인하였다. $\mathrm{qRT}-$ $\mathrm{PCR}$ 로 $M M P 1$ 의 $\mathrm{mRNA}$ 발현량을 확인한 결과, 자외선을 조 사하지 않은 세포에서 $M M P 1$ 발현 대비 $296.35 \%$ 까지 증가된 $M M P 1$ 의 발현이 $100,200 \mu \mathrm{g} / \mathrm{mL}$ 천궁추출물에 의해서 각각 $254.26,172.36 \%$ 까지 감소됨을 확인할 수 있었다(Figure 2). 


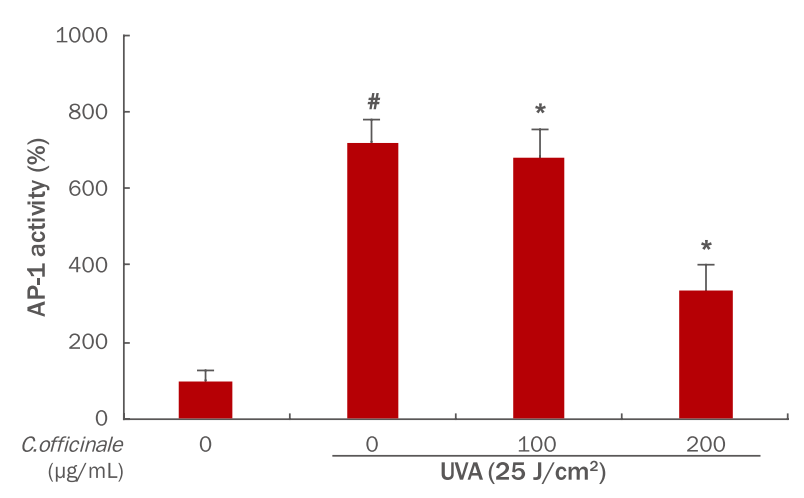

Figure 3. Effects of extracts of $C$. officinale on AP-1 transcriptional activity in human dermal fibroblasts.

Effects of AP-1 transcriptional activity was measured by TREcontained luciferase report plasmid. TRE is DNA binding site of AP-1. AP-1 transcriptional activity was normalized by $\beta$-galactosidase assay. The graphs are expressed as the $\mathrm{M} \pm \mathrm{S}$. D. from triplicate experiments. $C$. officinale, Cnidium officinale Makino; AP-1, activator protein 1; TRE, tet-responsive element; $" p<0.05$ compared with control cells. * $p<0.05$ compared with UVA-exposed cells; UVA, ultraviolet A; M \pm S.D., mean \pm standard deviation.

\section{3. 인간진피섬유아세포에서 천궁추출물에 의한 AP-1 전사활 성 변화}

광노화에서 $M M P 1$ 의 과발현은 주로 자외선이 $\mathrm{JNK}$ 의 인 산화를 증가시키고, 이에 따라 전사인자인 $\mathrm{AP}-1$ 의 전사활 성이 증가되어 $M M P 1$ 의 발현을 높이는 것으로 알려져 있다 (Hwang et al., 2013; Qin et al., 2014). 때문에 자외선 조 사환경에서 $M M P 1$ 의 발현을 조절하는 것으로 알려져 있는 $\mathrm{AP}-1$ 의 전사활성 변화를 확인하였다. Figure 3에서 보듯이, 자외선에 의해 $732.56 \%$ 증가된 $\mathrm{AP}-1$ 전사활성이 100,200 $\mu \mathrm{g} / \mathrm{mL}$ 천궁추출물에 의해서 $683.26,332.25 \%$ 로 농도의존 적으로 감소함을 확인할 수 있었다.

\section{4. 인간진피섬유아세포에서 천궁추출물에 의한 JNK 활성 변화}

자외선에 의한 광노화에서 $\mathrm{AP}-1$ 의 조절은 주로 $\mathrm{JNK}$ 에 의 해서 조절되기 때문에 $\mathrm{JNK}$ 의 활성을 확인하였다(Hwang et al., 2013; Qin et al., 2014). JNK는 인산화를 통해서 활성 이 조절되기 때문에 phosphor-JNK의 양을 비교하여 JNK 활성을 확인하였다. Figure 4에서 보는 바와 같이 자외선에 의해서 급격하게 증가된 phosphor-JNK가 천궁추출물의 처 리에 의해서 농도의존적으로 감소함을 확인할 수 있었다.
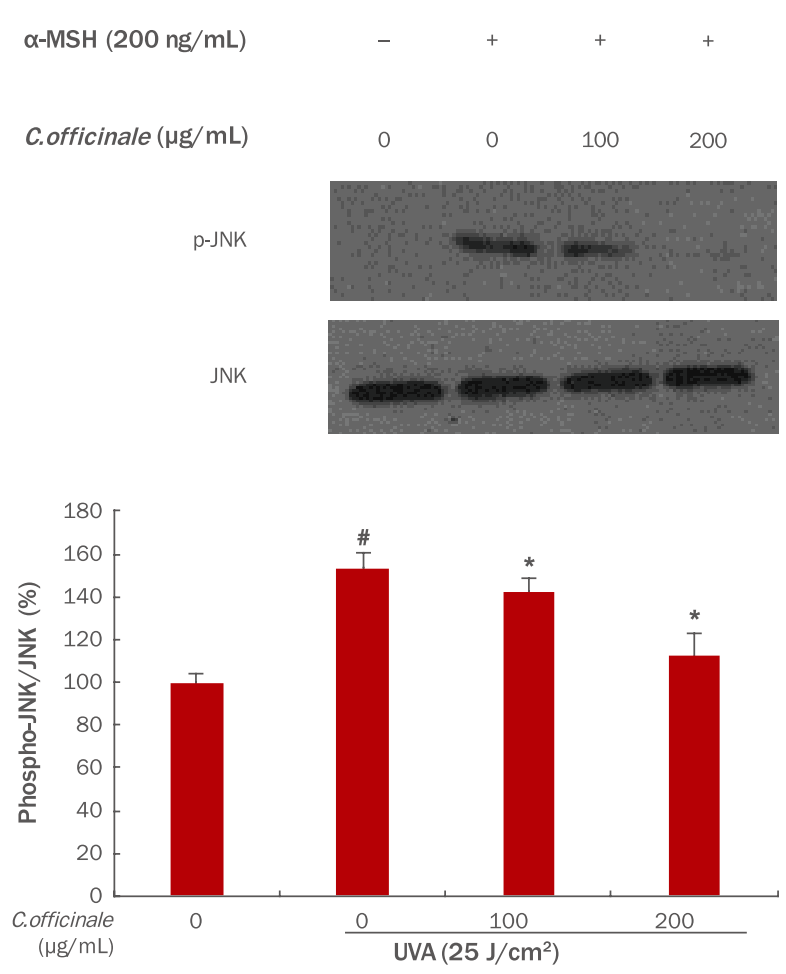

Figure 4. Effects of extracts of $C$. officinale on JNK phosphorylation in human dermal fibroblasts.

Effects of JNK activity was measured by western blot of JNK and phospho-JNK. After western blot, each band density was digitized by densitometer. JNK activity was normalized by normal JNK. The graphs are expressed as the $M \pm S$.D. from triplicate experiments. $C$. officinale, Cnidium officinale Makino; JNK, c-Jun N-terminal protein kinase; ${ }^{*} p<0.05$ compared with control cells; ${ }^{*} p<0.05$ compared with UVAexposed cells; UVA, ultraviolet A; M \pm S.D., mean \pm standard deviation.

\section{Conclusion}

본 논문은 천궁추출물의 항노화기전을 확인하고자 하였다. 본 논문의 결과에서 보는 것과 같이 천궁추출물은 $200 \mu \mathrm{g} / \mathrm{mL}$ 이하의 농도에서는 세포 독성이 없는 것을 확인하였으며, 따 라서 $200 \mu \mathrm{g} / \mathrm{mL}$ 이하에서 자외선에 의해 증가된 $M M P 1$ 발현 을 감소시키는 것을 확인하였다. 또한 이러한 $M M P 1$ 의 조절은 mitogen-activated protein kinase (MAPK)의 하나인 JNK 활성변화를 통한 $\mathrm{AP}-1$ 의 전사활성을 감소시켰기 때문으로 확 인할 수 있었다. 자외선은 세포내 활성산소를 증가시키고 이 를 통해서 $\mathrm{JNK}$ 를 활성화시킨다. $\mathrm{AP}-1$ 의 전사활성이 증가하 고, $\mathrm{AP}-1$ 의 조절을 받는 $M M P 1$ 의 발현이 증가하여 피부 노 화를 유도하는 것으로 알려져 있다. 천궁추출물은 많은 논문 을 통해서 다양한 항산화 물질이 함유되어 있는 것으로 알려 져 있다. 이러한 항산화 물질이 작용하여 자외선에 의한 활성 
산소 생성을 억제함으로써 JNK의 인산화를 억제할 수 있을 것으로 예측된다. 본 연구결과를 통해서 천궁추출물은 피부 의 collagen을 분해하는 $M M P 1$ 의 발현을 감소시켜 collagen 의 분해를 조절할 수 있는 화장품원료임을 확인하였고, 때문 에 새로운 주름개선 기능성화장품성분으로서 가능성을 제시해 주고 있다.

\section{Acknowledgements}

이 논문은 2017 년도 오산대학교 교내 학술비지원에 의해서 수행됨.

\section{References}

Bae JY, Choi JS, Kang SW, Lee YJ, Park J, Kang YH. Dietary compound ellagic acid alleviates skin wrinkle and inflammation induced by UV-B irradiation. Experimental Dermatology, 19: 182-190, 2010.

Chiang HM, Chen HC, Lin TJ, Shih IC, Wen KC. Michelia alba extract attenuates UVB-induced expression of matrix metalloproteinases via MAP kinase pathway in human dermal fibroblasts. Food and Chemical Toxicology, 50: 4260-4269, 2012.

Chung JH, Seo JY, Choi HR, Lee MK, Youn CS, Rhie G, Cho $\mathrm{KH}$, Kim KH, Park KC, Eun HC. Modulation of skin collagen metabolism in aged and photoaged human skin in vivo. Journal of Investigative Dermatology, 117: 1218-1224, 2001.

Cho S, Lee DH, Won CH, Kim SM, Lee S, Lee MJ, Chung JH. Differential effects of low-dose and high-dose betacarotene supplementation on the signs of photoaging and type I procollagen gene expression in human skin in vivo. Dermatology, 221: 160-171, 2010.

Choi HS, Kim MSL, Sawamura M. Constituents of the essential oil of cnidium officinale Makino, a Korean medicinal plant. Flavour and Fragrance Journal, 17: 49$53,2002$.

Choi SJ, Lee SN, Kim K, Joo da H, Shin S, Lee J, Lee HK, Kim J, Kwon SB, Kim MJ, et al. Biological effects of rutin on skin aging. International Journal of Molecular Medicine, 38: 357-363, 2016.

Chevallier A. The encyclopedia of medicinal plants. Dorling Kindersley Publishing, London, pp256-336, 2000.

Epstein EH Jr, Munderloh NH. Human skin collagen. presence of type I and type III at all levels of the dermis. The Journal of Biological Chemistry, 253: 1336-1337, 1978.

Haranaka K, Satomi N, Sakurai A, Haranaka R, Okada N, Kobayashi M. Antitumor activities and tumor necrosis factor producibility of traditional Chinese medicines and crude drugs. Cancer Immunology, Immunotherapy, 20: 1-5, 1985.

Hibi M, Lin A, Smeal T, Minden A, Karin M. Identification of an oncoprotein- and UV-responsive protein kinase that binds and potentiates the c-Jun activation domain. Genes \& Development, 7: 2135-2148, 1993.

Higashi K. The therapeutic effect of Unsei-in on facial redness (inflammatory congestion) in atopic dermatitis. The Japanese Journal of Oriental Medicine, 46: 753759, 1996.

Hwang BM, Noh EM, Kim JS, Kim JM, You YO, Hwang JK, Kwon KB, Lee YR. Curcumin inhibits UVB-induced matrix metalloproteinase-1/3 expression by suppressing the MAPK-p38/JNK pathways in human dermal fibroblasts. Experimental Dermatology, 22: 371-374, 2013.

Jang YA. Efficacy of a cosmetic material from complex extracts of Vaccinium spp., Phellinus linteus, Castanea crenata, and Cimicifuga heracleifolia. Asian Journal of Beauty and Cosmetology, 15: 281-290, 2017.

Janulis M, Silberman S, Ambegaokar A, Gutkind JS, Schultz RM. Role of mitogen-activated protein kinases and c-Jun/AP-1 trans-activating activity in the regulation of protease mRNAs and the malignant phenotype in $\mathrm{NIH}$ 3T3 fibroblasts. The Journal of Biological Chemistry, 274: 801-813, 1999.

Kalinin AE, Kajava AV, Steinert PM. Epithelial barrier function: assembly and structural features of the cornified cell envelope. BioEssays, 24: 789-800, 2002.

Kim HH, Shin CM, Park CH, Kim KH, Cho KH, Eun HC, Chung $\mathrm{JH}$. Eicosapentaenoic acid inhibits UV-induced MMP1 expression in human dermal fibroblasts. Journal of Lipid Research, 46: 1712-1720, 2005.

Lee CW, Choi HJ, Kim HS, Kim DH, Chang IS, Moon HT, Lee SY, Oh WK, Woo ER. Biflavonoids isolated from Selaginella tamariscina regulate the expression of matrix metalloproteinase in human skin fibroblasts. Bioorganic \& Medicinal Chemistry, 16: 732-738, 
2008.

Lee JJ, Kim KB, Heo J, Cho DH, Kim HS, Han SH, Ahn KJ, An IS, An S, Bae S. Protective effect of Arthrospira platensis extracts against ultraviolet B-induced cellular senescence through inhibition of DNA damage and matrix metalloproteinase-1 expression in human dermal fibroblasts. Journal of Photochemistry and Photobiology B: Biology, 173: 196-203, 2017.

Overall CM, López-Otin C. Strategies for MMP inhibition in cancer: innovations for the post-trial era. Nature Reviews Cancer, 2: 657-672, 2002.

Onishi Y, Yamaura T, Tauchi K, Sakamoto T, Tsukada K, Nunome S, Komatsu Y, Saiki I. Expression of the antimetastatic effect induced by Juzen-taiho-to is based on the content of Shimotsu-to constituents. Biological and Pharmaceutical Bulletin, 21: 761-765, 1998.

Qin Z, Voorhees JJ, Fisher GJ, Quan T. Age-associated reduction of cellular spreading/mechanical force upregulates matrix metalloproteinase-1 expression and collagen fibril fragmentation via c-Jun/AP-1 in human dermal fibroblasts. Aging Cell, 13: 1028-1037, 2014.

Tahara E, Satoh T, Toriizuka K, Nagai H, Nunome S, Shimada Y, Itoh T, Terasawa K, Saiki I. Effect of Shimotsu-to (a
Kampo medicine, Si-Wu-Tang) and its constituents on triphasic skin reaction in passively sensitized mice. Journal of Ethnopharmacology, 68: 219-228, 1999.

Tran TA, Ho MT, Song YW, Cho M, Cho SK. Camphor induces proliferative and anti-senescence activities in human primary dermal fibroblasts and inhibits UVinduced wrinkle formation in mouse skin. Phytotherapy Research, 29: 1917-1925, 2015.

Wang JD, Narui T, Kurata H, Takeuchi K, Hashimoto T, Okuyama T. Hematological studies on naturally occurring substances. Il. effects of animal crude drugs on blood coagulation and fibrinolysis systems. Chemical and Pharmaceutical Bulletin, 37: 2236-2238, 1989.

Werb Z. ECM and cel/ surface proteolysis: regulating cellular ecology. Cell, 91: 439-442, 1997.

Whitmarsh AJ, Davis RJ. Transcription factor AP-1 regulation by mitogen-activated protein kinase signal transduction pathways. Journal of Molecular Medicine, 74: 589607, 1996.

Yu H, Huang J, Wang S, Zhao G, Jiao X, Zhu L. Overexpression of Smad7 suppressed ROS/MMP9-dependent collagen synthesis through regulation of heme oxygenase- 1 . Molecular Biology Reports, 40: 5307-5314, 2013. 


\section{국문초록}

\section{인간진피섬유아세포에서 천궁추출물의 MMP1 발현 조절 기전}

김영주

오산대학교 뷰티케어코스메틱과, 경기도 오산시, 한국

목적: 천궁은 산형과에 속하는 약초로써 중국이 원산지이고, 한국, 중국, 일본에서 많이 사용되어 왔다. 천궁은 진통, 항염증, 월경 개선, 비타민 결핍증 억제 및 고혈압에 약으로 사용되어 왔다. 하지만 아직 피부에서의 역할은 알려지지 않았다. 때문에 본 연구에 서는 천궁의 인간진피섬유아세포에서의 역할을 확인하고자 한다. 방법: 천궁에 의한 matrix metalloproteinase-1 (MMP1)의 발현 변화는 quantitative real time polymerase chain reaction (qRT-PCR)로 확인하였고, 추가로 activator protein 1 (AP-1)과 c-Jun $\mathrm{N}$-terminal protein kinase (JNK)의 활성은 각각 luciferase assay와 western blot을 통해서 확인하였다. 결과: 자외선에 의해서 증 가된 $M M P 1$ 의 발현이 천궁추출물에 의해 다시 감소되었다. 또한 자외선이 조사된 인간진피섬유아세포에서 천궁추출물은 $\mathrm{AP}-1$ 의 전사활성을 감소시키고, JNK의 인산화를 감소시키는 것으로 확인되었다. 결론: 본 논문의 연구결과를 통해서 천궁추출물은 $\mathrm{AP}-1$ 과 JNK 인산화를 조절함으로써 $M M P 1$ 의 발현을 감소시킴을 알 수 있다. 때문에 천궁추출물은 피부의 collagen 분해하는 $M M P 1$ 의 발현을 감소시켜 collagen의 분해를 조절할 수 있는 화장품원료로서 가능성을 가지고 있다.

핵심어: MMPs, AP-1, JNK, Cnidium officinale Makino, UV

이 논문은 2017년도 오산대학교 교내 학술비지원에 의해서 수행됨.

\section{참고문헌}

장영아. 블루베리, 상황, 율피, 승마 복합추출물의 화장품 소재로서의 효능. 아시안뷰티화장품학술지, 15: 281-290, 2017. 


\section{中文摘要}

\section{川芎提取物对人真皮成纤维细胞MMP1表达的抑制作用}

金英珠

乌山大学美容化妆品学科，京畿道乌山市，韩国

目的：川芎属于伞形科，是中国本土的药用植物，在韩国、中国和日本广泛种植。川芎已被用于治疗疼痛，炎症， 月经紊乱和抗维生素缺乏症的东方药物, 也可用作降压药。然而, 在皮肤中并不完全了解川芎的效果。因此, 在本 研究中, 确认川芎在人真皮成纤维细胞中的作用。方法: 为确认川芎的作用, 利用quantitative real time polymerase chain reaction (qRT-PCR)测量matrix metalloproteinase-1 (MMP1)的表达, 利用luciferase assay和western blot分别测 量activator protein 1 (AP-1)和c-Jun N-terminal protein kinase (JNK)的活性。结果: 川䒮提取物降低紫外线照射增加的 $M M P 1$ 的表达。此外，川芎提取物在人真皮成纤维细胞中，降低AP-1的转录活性和JNK的磷酸化。结论: 研究结果表明川 芎提取物通过调节AP-1和JNK的磷酸化降低MMP1的表达。因此, 川芎提取物减少了分解胶原蛋白质的MMP1的表达, 作 为调节胶原蛋白质分解的化妆品原料充分具有可行性。

关键词: MMPs, AP-1, JNK，川芎，紫外线 